\title{
Antimicrobial Activity of the Essential Oil from Hyptis carpinifolia Benth
}

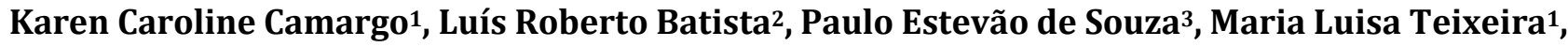 \\ Thaís Aparecida Sales ${ }^{1}$, Vanuzia Rodrigues Fernandes Ferreira ${ }^{1}$, Jéssica Oliveira e Nogueira ${ }^{1}$, \\ Maísa Lamounier Magalhães², Alex Rodrigues Silva Caetano1, David Lee Nelson4, \\ Maria das Graças Cardoso ${ }^{1^{*}}$ \\ ${ }^{1}$ Department of Chemistry, Federal University of Lavras, Lavras, Brazil \\ ${ }^{2}$ Department of Food Science, Federal University of Lavras, Lavras, Brazil \\ ${ }^{3}$ Department of Phytopathology, Federal University of Lavras, Lavras, Brazil \\ ${ }^{4}$ Pro-Rectory of Research and Graduate Studies, Federal University of the Jequitinhonha and Mucuri Valleys, Diamantina, Brazil \\ Email: *mcardoso@dqi.ufla.br
}

How to cite this paper: Camargo, K.C., Batista, L.R., de Souza, P.E., Teixeira, M.L., Sales, T.A., Ferreira, V.R.F., e Nogueira, J.O., Magalhães, M.L., Caetano, A.R.S., Nelson, D.L. and das Graças Cardoso, M. (2017) Antimicrobial Activity of the Essential Oil from Hyptis carpinifolia Benth. American Journal of Plant Sciences, 8, 2871-2877. https://doi.org/10.4236/ajps.2017.811195

Received: August 15, 2017

Accepted: October 27, 2017

Published: October 30, 2017

Copyright $\odot 2017$ by authors and Scientific Research Publishing Inc. This work is licensed under the Creative Commons Attribution International License (CC BY 4.0).

http://creativecommons.org/licenses/by/4.0/ (c) (i) Open Access

\begin{abstract}
Essential oils are secondary metabolites whose biological properties have been studied with emphasis on antimicrobial activity. Hyptis carpinifolia Benth (Rosmaninho) is used in folk medicine in the fight against colds and rheumatism. The objective of this study was to evaluate the antimicrobial activity of the essential oil from $H$. carpinifolia. The essential oil was extracted by hydrodistillation using a modified Clevenger apparatus. The biological activity was determined using the Agar Cavity Diffusion technique to evaluate the effect of concentrations of $500,250,125,62.5,31.25,15.62,7.81$ and $3.9 \mu \mathrm{g} \cdot \mathrm{mL}^{-1}$ on the bacteria Escherichia coli, Listeria monocytogenes, Salmonella Choleraesuis, Staphylococcus aureus and Pseudomonas aeruginosa. The fungicidal potential was evaluated by the method of dilution in agar, and the percentage inhibition of mycelial growth of Alternaria alternata, Botrytis cinerea and $\mathrm{Fu}$ sarium oxysporum was evaluated. The dilutions tested were 1000, 750, 500, 250 and $100 \mu \mathrm{L} \cdot \mathrm{L}^{-1}$. The minimum inhibitory concentrations (MIC) of the essential oil for L. monocytogenes, $S$. aureus and E. coli were 31.25; 15.62 and $62.5 \mu \mathrm{g} \cdot \mathrm{mL}^{-1}$, respectively. The MIC was $500 \mu \mathrm{g} \cdot \mathrm{mL}^{-1}$ for Salmonella Choleraesuis and $P$. aeruginosa. The percentage inhibitions of mycelial growth of $B$. cinerea and $A$. alternate were $67 \%$ and $33 \%$, respectively, at the dilution of 750 $\mu \mathrm{L} \cdot \mathrm{L}^{-1}$. The essential oil inhibited about $48 \%$ of the mycelial growth of $F$. oxysporum, at the dilution of $1000 \mu \mathrm{L} \cdot \mathrm{L}^{-1}$. The essential oil of $H$. carpinifolia presented biological activity against all the microorganisms evaluated.
\end{abstract}

\section{Keywords}

Essential Oils, Antimicrobial Activity 


\section{Introduction}

Bacteria and fungi can have beneficial or detrimental effects on human beings. The beneficial actions involve the synthesis of drugs and the production of wine, cheeses and yoghurts. However, they can also be pathogenic microorganisms and can cause damage to humans, animals and crops [1].

One of the major public health problems facing the world is the contamination of food by pathogenic microorganisms, which cause damage to consumer health and major economic losses. Among these microorganisms are the bacteria Salmonella ssp, Listeria monocytogenes and Escherichia coli, which are responsible for a large number of cases of diseases and mortality [2].

Phytopathogenic fungi are also a concern for agriculture because they represent a limiting factor for production and cause losses in productivity and quality of agricultural products. Among these fungi, Fusarium oxysporum, Botrytis cinerea and Alternaria alternata are highlighted because they are very detrimental to the farmer's income because they attack a wide variety of plants [3] [4] [5].

Both in the food industry and in agriculture, these microorganisms are controlled by the use of synthetic products; however, studies report that the continuous use of these products can provoke resistance in the target pathogens so that it is necessary to increase the dosage with each application. Because synthetic products can cause damage to human health and the environment, it is necessary to replace them with natural products that are less aggressive and ecologically safe.

Essential oils are complex mixtures of volatile, lipophilic, liquid and odoriferous substances produced through the secondary metabolism of plants. These oils have numerous biological activities, such as antioxidant, anti-inflammatory, anti-tumoral, fungicidal, bactericidal, and insecticidal activities, that make their use prominent in the pharmaceutical, food, perfumery and cosmetic industries [6].

One plant that has been explored in folk medicine for the treatment of colds, flu and rheumatism is Hyptis carpinifolia Benth, popularly known as rosmaninho. This is a herbaceous plant that belongs to the Lamiaceae family and can be found among several plant formations [7]. The objective of this work was to evaluate the biological potential of the essential oil from $H$. carpinifolia against food-borne bacteria and phytopathogenic fungi.

\section{Material and Methods}

\subsection{Obtaining Plant Material and Extracting the Essential Oil}

The leaves of $H$. carpinifolia were collected in the municipality of Itumirim, MG, Brazil, on February 6, 2014, in the morning of a day without precipitation. The identification of the plant species was performed by Professor Mariana Esteves Mansandres of the Department of Biology of the Federal University of Lavras, and the exsicta was deposited in the ESAL Herbarium under the registry number 28.489. The extraction of the essential oil was performed over a 2 -hr period at 
$\pm 98^{\circ} \mathrm{C}$ in the Laboratory of Organic Chemistry-Essential Oils, DQI, of the same University with a modified Clevenger apparatus using the hydrodistillation technique [8].

\subsection{Antibacterial Activity of the Essential Oil}

The antibacterial activity was determined using the Agar Cavity Diffusion technique according to the method described by Silva et al. [9]. The bacteria evaluated were Escherichia coli ATCC 11229, Listeria monocytogenes ATCC 19117, Salmonella Choleraesuis ATCC 6539, Staphylococcus aureus ATCC 6538 and Pseudomonas aeruginosa ATCC 11229, which were furnished by the UFLA Department of Food Sciences microorganism culture collection.

The cultures were spiked in Brain and Heart Infusion Broth (BHI), incubated at $37^{\circ} \mathrm{C}$ for 24 hours and transferred to a tube containing $5 \mathrm{~mL}$ of Tryptic Soybean Broth (TSB), which was incubated again under the same conditions until it reached the turbidity of a McFarland standard solution of 0.5 , corresponding to the concentration of $10^{8} \mathrm{CFU} \mathrm{mL}$. The inoculums were then diluted to the concentration of $10^{6} \mathrm{CFU} \mathrm{mL} \mathrm{m}^{-1}$ and incorporated into Mueller-Hinton Agar.

A thin layer of pure Mueller-Hinton Agar was poured into the Petri dishes and sterile glass beads were placed on the gel. The agar in which the bacterium was inoculated was poured over the first layer. After solidification, the glass beads were removed, and $10 \mu \mathrm{l}$ of the essential oil at concentrations of 500, 250, 125, $62.5,31.25,15.62,7.81$ and $3.9 \mu \mathrm{g} \cdot \mathrm{mL}^{-1}$ in DMSO was added to each well. The experiment was performed in triplicate using the antibiotic chloramphenicol as a positive standard and DMSO as a negative standard. The plates were incubated in $\mathrm{BOD}$ at $37^{\circ} \mathrm{C}$, and the diameters of the inhibition halos were measured after 24 hours. The lowest inhibitory concentration (MIC) was defined as the lowest concentration capable of promoting inhibition of the bacteria under study.

\subsection{Antifungal Activity of the Essential Oil}

The antifungal potential of the essential oil from $H$. carpinifolia was evaluated by the Agar Dilution method performed at the Mycology Laboratory of the Department of Plant Pathology (DFP) at UFLA. The cultures were provided by the DFP Library of the same University, with the registration numbers CML-1606 (Alternaria alternata), CML-2317 (Botrytis cinerea) and CML-2724 (Fusarium oxysporum).

The essential oil was diluted in $1 \%$ Tween 80 /water solution at the concentrations of $1000,750,500,250$ and $100 \mu \mathrm{L} \cdot \mathrm{L}^{-1}$. The resulting solutions were incorporated into the semi-solid culture medium (Malt) using a modification of the method described by Klančnik et al. [10]. After solidification of the culture medium, disks ( $7 \mathrm{~mm}$ diameter) of the fungal cultures were added to the center of each plate. The plates were sealed with plastic film and stored in a growth chamber at a temperature of $25^{\circ} \mathrm{C}$ and with a photoperiod of 12 hours.

The experiment was performed using four replicates, including the absolute 
control (malt medium without the addition of solvent) and relative control (culture media and solvent). The evaluations were performed by measuring the orthogonal diameters of mycelial growth when a $100 \%$ fungus colony growth was observed in the absolute control. The results were submitted to statistical analysis using the ANOVA method (completely randomized experimental design), comparing the means of inhibition of mycelial growth by the Scott-Knott test at the $5 \%$ probability level.

\section{Results and Discussion}

\subsection{Antibacterial Activity of the Essential 0il}

The results of the determination of the antibacterial activity of the essential oil from $H$. carpinifolia against the bacteria evaluated are presented in Table 1. Inhibition halos for both Gram-positive and Gram-negative bacteria were observed after exposure to the essential oil, and Gram-positive bacteria were observed to be more sensitive. Studies have reported that the higher resistance of Gram-negative bacteria can be attributed to the presence of an outer membrane in its structure that might hinder the penetration and action of essential oil constituents [2]. Among the Gram-positive bacteria, L. monocytogenes was more resistant than $S$. aureus, whereas Gram-negative $E$. coli were more susceptible to the action of the essential oil, and the other bacteria were only inhibited at the highest concentration assessed.

Species belonging to the Lamiaceae family are highlighted in the literature because they have notorious effects on microorganisms. In a bibliographic survey performed by Falcão and Mendes [11], species belonging to the Hyptis genus, $H$. suaveolens and $H$. pectinata, were cited as important antibacterial agents against pathogens of Gram-positive and Gram-negative origin. Nikolic et al. [12] obtained significant results when they evaluated the antibacterial activity of three essential oils of the Thymus genus, T. serpyllum, T. algeriensis and T. vulgaris, and observed MIC values ranging from 2.5 to $160 \mu \mathrm{g} \cdot \mathrm{mL}^{-1}$, equivalent to the antibiotics Hexoral, Streptomycin and Ampicillin. A considerable antibacterial potential against bacteria associated with food outbreaks, such as $S$. aureus, L. monocytogenes and E. coli, which were also investigated in the present study, was

Table 1. Minimum Inhibitory Concentration (MIC) of the essential oil the H. carpinifolia for the bacteria under study.

\begin{tabular}{ccccc}
\hline Bacterium & Gram & CL & DMSO & $\mathrm{MIC}\left(\mu \mathrm{g} \cdot \mathrm{mL}^{-1}\right)$ \\
\hline L. monocytogenes & + & I & NI & 31.25 \\
S. aureus & + & I & NI & 15.62 \\
E. coli & - & I & NI & 62.5 \\
S. Choleraesuis & - & I & NI & 500 \\
P. aeruginosa & - & I & NI & 500
\end{tabular}

$\mathrm{I}=$ Inhibition; NI = No Inhibition; CL = Chloramphenicol. 
observed by Shahbazi [13] for Mentha spicata.

\subsection{Antifungal Activity of the Essential Oil}

The results obtained in the evaluation of the antifungal potential of $H$. carpinifolia were expressed as percentage inhibition of the mycelial growth of $F$. oxysporum, B. cinerea and $A$. alternate. The results are presented in Table 2.

There was a dose-dependent relationship between the treatments and the three fungi; the application of a concentration of $750 \mu \mathrm{L} \cdot \mathrm{L}^{-1}$ resulted in approximately $67 \%$ and $33 \%$ inhibition of the growth of $B$. cinerea and $A$. alternata, respectively. About $48 \%$ of the mycelial growth of $F$. oxysporum was inhibited by a concentration of $1000 \mu \mathrm{L} \cdot \mathrm{L}^{-1}$ of the essential oil.

Among the three fungi, $B$. cinerea was the most sensitive to the essential oil of $H$. carpinifolia. Lorenzetti et al. [4] evaluated the influence of several essential oils on the mycelial growth of this same pathogen and observed inhibition by the essential oils extracted from plants belonging to the Lamiaceae family, Mentha pipertita (peppermint), Lavandula hybrida (lavender) and Rosmarinus officinalis (rosemary). Corroborating with these results, Soylu et al. [14] obtained the same effect on $B$. cinerea in tomatões when they evaluated the efficacy of essential oils extracted from Origanum syriacum (oregano), L. stoechas (lavender) and $R$. officinalis (rosemary), all of which belong to the Lamiaceae family.

Essential oils extracted from members of the Lamiaceae family were also instrumental in a study by Kumar et al. [15]. The authors evaluated the influence of Nepeta leucophylla, Nepeta ciliaris, Nepeta clarkei and Calamintha umbrosa in the control of pathogens responsible for damage to several food crops. All the oils exhibited potent biofungicidal activity. At the concentration of $500 \mu \mathrm{g} \cdot \mathrm{mL}^{-1}$, the fungi most sensitive to the action of the essential oils were $F$. oxysporum, Helminthosporium maydis and Rhizoctonia solani, for which the percentage of inhibition ranged from 67 to $74 \%, 76$ to $88 \%$, and 74 to $77 \%$, respectively. At this

Table 2. Percent inhibition of the mycelial growth by different concentrations of the essential oil from Hyptis carpinifolia Benth.

\begin{tabular}{cccc}
\hline & & Percent inhibition & \\
Treatment $\left(\mu \mathrm{L} \cdot \mathrm{L}^{-1}\right)$ & $F$. oxysporum & B. cinerea & A. alternata \\
\cline { 2 - 4 } 100 & $0.00 \mathrm{eB}( \pm 0.00)$ & $6.25 \mathrm{~dB}( \pm 3.71)$ & $20.89 \mathrm{cA}( \pm 1.07)$ \\
250 & $8.21 \mathrm{~dB}( \pm 0.00)$ & $20.71 \mathrm{cA}( \pm 1.30)$ & $23.04 \mathrm{cA}( \pm 2.69)$ \\
500 & $24.46 \mathrm{cB}( \pm 5.36)$ & $42.14 \mathrm{bA}( \pm 10.84)$ & $29.50 \mathrm{bB}( \pm 5.20)$ \\
750 & $38.57 \mathrm{bB}( \pm 7.98)$ & $66.61 \mathrm{aA}( \pm 9.01)$ & $33.39 \mathrm{aB}( \pm 2.29)$ \\
1000 & $48.39 \mathrm{aB}( \pm 3.25)$ & $69.46 \mathrm{aA}( \pm 6.58)$ & $37.14 \mathrm{aC}( \pm 6.09)$ \\
Absolute control & $0.00 \mathrm{e}( \pm 0.00)$ & $0.00 \mathrm{e}( \pm 0.00)$ & $0.00 \mathrm{~d}( \pm 0.00)$ \\
Relative control & $0.00 \mathrm{e}( \pm 0.00)$ & $0.00 \mathrm{e}( \pm 0.00)$ & $0.00 \mathrm{~d}( \pm 0.00)$
\end{tabular}

*The means followed by the same letter in the same column (lower case) and in the same line (upper case) do not differ statistically from one another by the Scott-Knott test at the $5 \%$ probability level. 
same concentration, the essential oils accounted for approximately 44 to $55 \%$ and 63 to $64 \%$ inhibition of the mycelial growth of $A$. solani and Sclerotonia sclerotiorum, respectively.

Evaluating the influence of the essential oil from Zataria multiflora (Lamiaceae) on Alternaria alternate, Mahmoudi et al. [16] noted a 100\% inhibition of spore germination, in addition to morphological changes observed by electron microscopy. Mycelial growth of the pathogen was totally inhibited at concentrations of 200 and 500 ppm.

\subsection{Conclusion}

In general, it can be considered that the essential oil from Hyptis carpinifolia Benth presented biological activity against all the pathogens evaluated. However, further testing is necessary to confirm the biological potential prior to commercialization.

\section{Acknowledgements}

The authors are grateful to the Conselho Nacional de Desenvolvimento Científico e Tecnológico $(\mathrm{CNPq})$, the Fundação de Amparo à Pesquisa do Estado de Minas Gerais (FAPEMIG), the Coordenação de Aperfeiçoamento de Pessoal de Nível Superior (CAPES) and the Universidade Federal de Lavras for their financial support and support for the execution of this research.

\section{References}

[1] Lopes, A.A., et al. (2011) Quando os micro-organismos salvam vidas: Seres diminutos a serviço da produção de medicamentos. [When Microorganisms Save Lives: Tiny Beings for the Production of Medicines.] Ciênciahoje, 48, 30-35.

[2] Valeriano, C., et al. (2012) Atividade antimicrobiana de óleos essenciais em bactérias patogênicas de origem alimentar. [Antimicrobial Activity of Essential Oils in Pathogenic Food-Borne Bacteria.] Revista Brasileira de Plantas Medicinais, 14, 57-67.

[3] Hoffmann, C.A., et al. (2015) Potencial de antagonismo de isolados de Trichoderma sp. contra o isolados de Fusarium sp., in vitro. [Potential Antagonism of Trichoderma sp. Isolates against Isolates of Fusarium sp. in vitro.] Revista Verde de Agroecologia e Desenvolvimento Sustentável. Pombal-PB, 10, 236-242.

[4] Lorenzetti, E.R., et al. (2011) Bioatividade de óleos essenciais no controle de Botrytis cinerea isolado de morangueiro. [Bioactivity of Essential Oils in the Control of $\mathrm{Bo}$ trytis cinerea Isolated from Strawberry.] Revista Brasileira de Plantas Medicinais, 13, 619-627.

[5] Vasconcelos, C.V., Silva, D.C. and Carvalho, D.D.C. (2014) Ocorrência de Alternaria alternata (Fr.:Fr.) Keissl. Em tubérculos de batata, no Brasil' [Occurrence of $A 1$ ternaria alternata (Fr.:Fr.) Keissl. in Potato Tubers in Brazil.] Pesquisa Agropecuária Tropical Goiania, 44, 219-222. http://www.agro.ufg.br/pat

[6] Asbahani, A.E., et al. (2015) Essential Oils: From Extraction to Encapsulation. International Journal of Pharmaceutics, 483, 220-243.

https://doi.org/10.1016/j.ijpharm.2014.12.069 
[7] Silva, I.C. and Moura, R.B. (2011) Espécies de Asteraceae e Lamiaceae Usadas na Medicina Popular da Região Sudeste para Problemas Respiratórios: O Que as Evidências Científicas Indicam. [Species of Asteraceae and Lamiaceae Used in Popular Medicine for Respiratory Problems in the Southeast Region: What the Scientific Evidence Indicates.] Revista Fitos, 6, No. 01.

[8] Farmacopéia Brasileira (2010) Agência Nacional de Vigilância Sanitária. 5th Edition, Anvisa, Brasília.

[9] Silva, L.F., et al. (2015) Chemical Characterization, Antibacterial and Antioxidant Activities of Essential Oils of Mentha viridis L. and Mentha pulegium L. American Journal of Plant Sciences, 6, 666-675. https://doi.org/10.4236/ajps.2015.65072

[10] Klancnik, A., et al. (2010) Evaluation of Diffusion and Dilution Methods to Determine the Antibacterial Activity of Plant Extracts. Journal of Microbiological Methods, 81, 121-126. https://doi.org/10.1016/j.mimet.2010.02.004

[11] Falcão, D.Q. and Menezes, F.S. (2003) Revisão etnofarmacológica, farmacológica e química do gênero Hyptis. [Ethnopharmacological, Pharmacological and Chemical Review of the Genus Hyptis.] Revista Brasileira de Farmácia, 84, 69-74.

[12] Nikolic, M., et al. (2014) Chemical Composition, Antimicrobial, Antioxidant and Antitumor Activity of Thymus serpyllum L., Thymus algeriensis Boiss. and Reut and Thymus vulgaris L. Essential Oils. Industrial Crops and Products, 52, 183-190. https://doi.org/10.1016/j.indcrop.2013.10.006

[13] Shahbazi, Y. (2015) Chemical Composition and Antibacterial Activity of Essential Oil against Common Food-Born Pathogenic Bacteria. Journal of Pathogens, 2015, 5 .

[14] Soylu, E.M., Kurt, S. and Soylu, S. (2010) In Vitro and in Vivo Antifungal Activities of the Essential Oils of Various Plants against Tomato Grey Mould Disease Agent Botrytis cinerea. International Journal of Food Microbiology, 143, 183-189. https://doi.org/10.1016/j.ijfoodmicro.2010.08.015

[15] Kumar, V., et al. (2014) In Vitro Inhibition Activity of Essential Oils from Some Lamiaceae Species against Phytopathogenic Fungi. Pesticide Biochemistry and Physiology, 114, 67-71. https://doi.org/10.1016/j.pestbp.2014.07.001

[16] Mahmoudi, E., et al. (2012) Effect of Zataria multiflora Essential oil on Alternaria alternate in Vitro and in an Assay on Tomato Fruits. Journal of Plant Diseases and Protection, 119, 53-58. 